\title{
ArcheoSciences
}

Revue d'archéométrie

33 (suppl.) | 2009

Mémoire du sol, espace des hommes

\section{Geophysical survey at archaeological sites in northeastern Syria}

Inna Mateiciucová, Peter Milo, Tomas Tencer and Marek Vlach

\section{(2) OpenEdition}

1 Journals

\section{Electronic version}

URL: https://journals.openedition.org/archeosciences/1385

DOI: 10.4000/archeosciences.1385

ISBN: 978-2-7535-1599-4

ISSN: 2104-3728

Publisher

Presses universitaires de Rennes

\section{Printed version}

Date of publication: 30 October 2009

Number of pages: 111-113

ISBN: 978-2-7535-0943-6

ISSN: $1960-1360$

\section{Electronic reference}

Inna Mateiciucová, Peter Milo, Tomas Tencer and Marek Vlach, "Geophysical survey at archaeological sites in northeastern Syria", ArcheoSciences [Online], 33 (suppl.) | 2009, Online since 30 October 2011, connection on 01 February 2022. URL: http://journals.openedition.org/archeosciences/1385 ; DOI: https://doi.org/10.4000/archeosciences. 1385 


\title{
Geophysical survey at archaeological sites in northeastern Syria
}

\author{
Inna Mateiciucová*, Peter Milo*, Tomáš Tencer* and Marek Vlach *
}

Key words: Magnetic prospection, Tell and non-tell settlements, Khabur region, Northeastern Syria.

From August 25 to September 4, 2008, geophysical surveys were carried out at the Neolithic, Chalcolithic, Bronze and Iron Age tell- and non-tell settlements in the Khabur region in Northeastern Syria (Syrian-Polish-Czech expedition) (Fig. 1). Four sites were prospected: Tell Arbid Abyad, Tell Arbid (West-hill), Khirbet Shane, Khirbet Bezi. The Scintrex Navmag SM-5 - Caesium Magnetometer was used for the measurement of the vertical gradient of the local magnetic field. The measurement resolution was $1.0 \times 0.15$ $\mathrm{m}$. The total prospected area was 11.25 ha (Fig. 2).

Field walking surveys were also conducted in the region. During these surveys an effort was made to verify some sites predicted (with high and low probability) by Jason Ur and Bjoern Menze (2007). The field artifact surveys were divided into two types, small- and large-scale, varied by purposes, method used, size of surveyed area and expected results. Large-scale surveys (89 ha) mapped regions near a local wadi, while small-scale surveys ( $23 \mathrm{ha}$ ) were focused on the archaeologically excavated Tell Arbid Abyad. Khirbet Bezi and Khirbet Shane were surveyed though they lie outside the main study area, because of expected Neolithic (Halab culture) period remains which are the main interest of the Czech part of the Syrian-Polish-Czech mission. More than 30 thousand sherds, weighing a total of $368 \mathrm{~kg}$, were collected during the survey. This archaeological material was used to create interpolated raster layers, for example, density counts of potsherds per square meter etc.
The first geophysical prospection of Tell Arbid was carried out in 2004 by Tomasz Herbich. He prospected about 6 hectares of the locality and detected a great number of magnetic anomalies indicating the presence of archaeological structures (Herbich, 2005, Fig. 1). Herbich's prospection results are very similar to the results of the 2008 prospection on the western mound, which is a smaller tell separated from Tell Arbid proper by a $50 \mathrm{~m}$ wide flat space. West-hill is not archaeologically excavated. Most of the surface finds can be dated to the Chalcolithic, Bronze and Iron Ages. Some finds were dated to more recent periods. The geophysical survey was carried out over the entire area of the hill ( 4 ha), registering a number of circular and oval-shaped anomalies varying in diameter from 1 to $5 \mathrm{~m}$. Magnetic value amplitudes ranged from c. 5 to $20 \mathrm{nT}$. Altogether 80 such anomalies were recorded. Some of these anomalies can be interpreted as possible fireplaces or kilns. T. Herbich interpreted such anomalies as pits with an ash-dominated filling. In 19961997 and in 2002, excavations to the north of his survey area revealed numerous pits of this kind. These pits were found at different depths and were dated to Hellenistic times (Bieliński, 1998 and 2003; Herbich, 2005, 493, fig. 1). A similar interpretation of such anomalies is viable for the magnetic map from West-hill. Analogous to anomalies from Herbich's survey, some of the anomalies with low magnetic values and less distinct in outline could be interpreted as deeper-lying pits.

Department of Archaeology and Museology. (inna.mateiciuc@mail.muni.cz) (milop@post.sk) (tomastencer@seznam.cz) (75464@mail.muni.cz) 


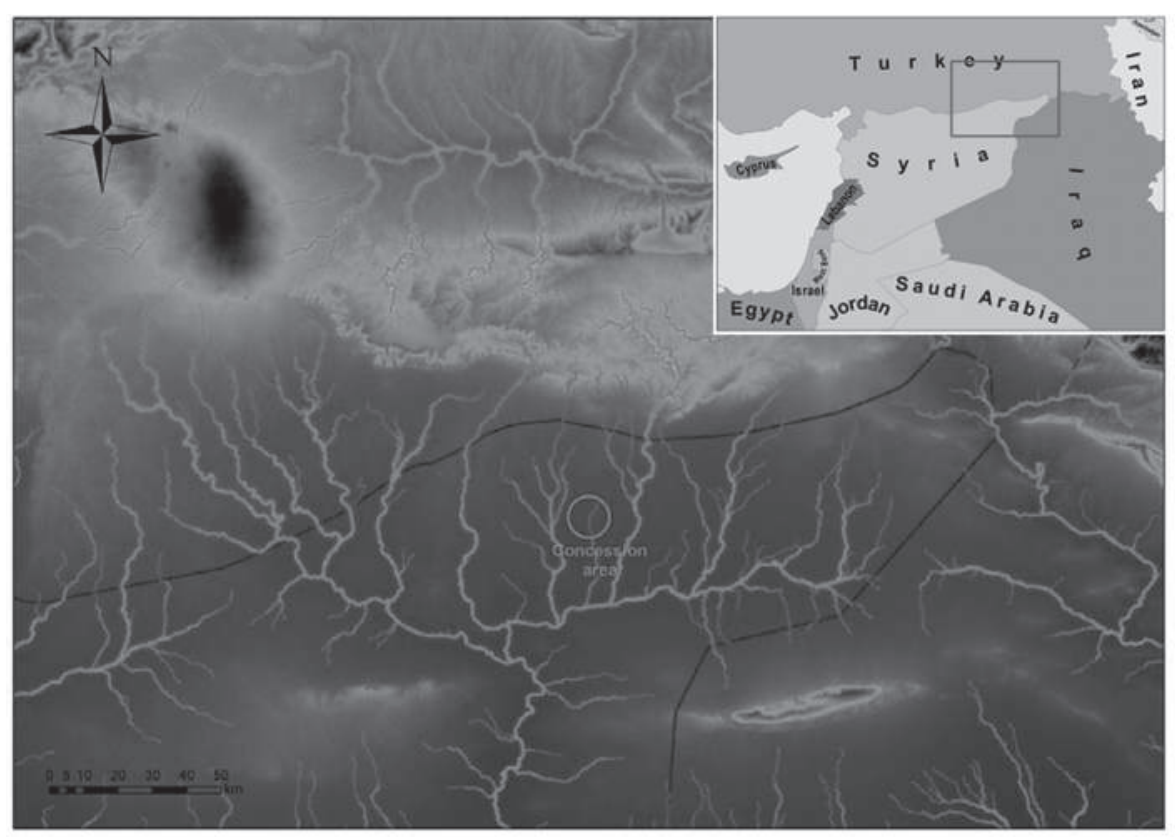

Figure 1: Map of the Khabur region (NE Syria) with digital elevation model (DEM), digitally reconstructed stream link and marked concession perimeter of Syrian-Polish-Czech mission.

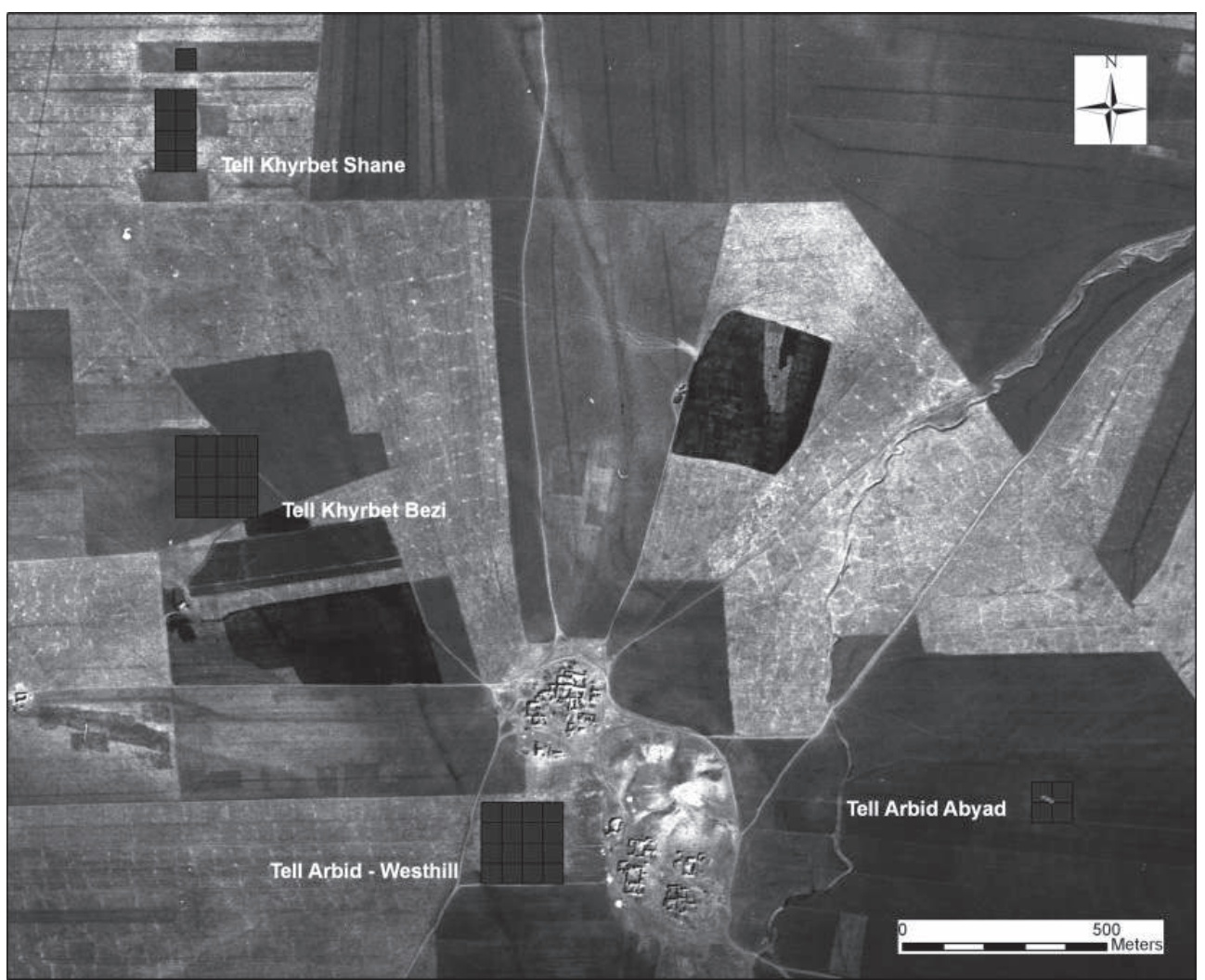

Figure 2: CORONA image of the area examined in 2008.
The second prospected site, Tell Arbid Abyad, lies about $1 \mathrm{~km}$ to the east of Tell Arbid village. Abyad is more like a non-tell site with the local elevation not more than $1 \mathrm{~m}$. Archaeological excavations were started here in 2005. The site was settled during the Neolithic period, Bronze Age,
Iron Age and medieval times. It is possible to date most of the excavated features to the Halaf culture. The geophysical prospection covered the whole of the tell remains (1 ha). However, no archaeological features could be detected. The magnetic anomalies can be interpreted mainly as traces of 


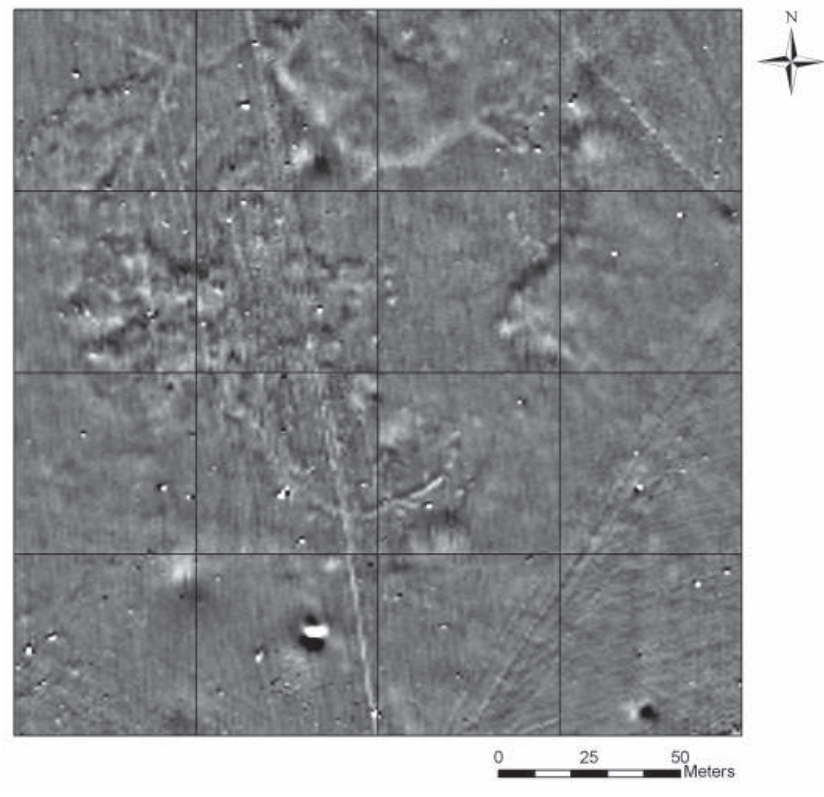

Figure 3: Tell Khirbet Bezi. Magnetic map.

intensive agricultural activities in the form of plow marks and field boundaries.

Better results were achieved at Khirbet Shane, which lies c. $1.5 \mathrm{~km}$ from Tell Arbid village and covers an area of about 6 hectares. The site was settled during the Neolithic period, Bronze Age and Iron Age. The total prospected area was $2.25 \mathrm{ha}$. The survey registered some circular and oval-shaped anomalies similar in shape and magnetic properties to those detected at Tell Arbid (West-hill). Other magnetic anomalies can be interpreted as traces of intensive agricultural activities.

The last geophysically prospected site was Khirbet Bezi (Fig. 3). The site lies about $1 \mathrm{~km}$ to the northwest of Tell Arbid village. The tell covers an area of about 1 ha and rises to a height of about $2 \mathrm{~m}$. Ceramic material from the field survey can be dated to the Halaf culture. The site has not been excavated archaeologically yet. The geophysical survey covered a total of 4 ha. The amplitude of magnetic values in the settlement area was between c. -3 to $6 \mathrm{nT}$. These differences are the result of the accumulation of settlement layers consisting mainly of extinct and destroyed buildings and a great amount of sherd material as well. The biggest density of archaeological features was identified in the central and western part of the prospected area. The survey registered four anomalies, which can be interpreted as houses. A linear structure in the eastern half of the magnetic map is to be interpreted as a possible river bank or terrace.

The geophysical survey results from the Khabour territory are different in several places. Modern agrarian cultivation is a serious problem at all sites. In many cases, the magnetic map is burdened by disturbances related to changes of surface relief and soil density in near-surface layers caused by deep plowing and the use of heavy-equipment. A clear definition of detected archaeological structures is in most cases impossible. However, geophysical prospection has proved to have big potential also in this region of Syria.

\section{References}

Bıeliński, P., 1998. Tell Arbid. Second campaign of Syro-Polish excavations. Polish Archaeology in the Mediterranean, 9: 212223.

BIELIŃsKI, P., 2003. Tell Arbid. The seventh season of excavations. Preliminary report. Polish Archaeology in the Mediterranean, 14: 301-314.

Herbich, T., 2005. Tell Arbid. Geophysical survey, 2004. Polish Archaeology in the Mediterranean, 16: 490-496

Menze, B. and UR, J., 2007. Classification of multispectral ASTER imagery in archaeological settlement survey in the Near East. In M.E. Schaepman, S. Liang, N. E. Groot, M. Kneubühler (dir.). Proceeding of the 10th International Symposium on Physical Measurements and Signature in Remote Sensing, Switzerland: Davos. International Archives of the Photogrammetry, Remote Sensing and Spatial Information Sciences, 36, 244-249. 